Lech Kotwicki - Marleen De Troch

Barbara Urban-Malinga · Tom Gheskiere

Jan Marcin Weslawski

\title{
Horizontal and vertical distribution of meiofauna on sandy beaches of the North Sea (The Netherlands, Belgium, France)
}

Received: 9 November 2004/ Revised: 23 May 2005/ Accepted: 25 May 2005/Published online: 16 July 2005

(c) Springer-Verlag and AWI 2005

\begin{abstract}
Sandy intertidal zones were analysed for the presence of meiofauna. The material was collected on six macro-tidal sandy beaches along the North Sea (The Netherlands, France, Belgium), in order to analyse the vertical and horizontal meiofaunal distribution patterns. Eleven higher meiofauna taxa (one represented by larval stage - Copepoda nauplii) were recorded. The maximum total meiofauna abundance was observed on the Dutch beach $\left(4,295 \pm 911\right.$ ind. $\left.10 \mathrm{~cm}^{-2}\right)$ in the Westerschelde estuary, while the lowest values $\left(361 \pm 128\right.$ ind. $\left.10 \mathrm{~cm}^{-2}\right)$ were recorded in France at the Audresselles beach. Meiofauna of the different localities consisted mainly of nematodes, harpacticoids and turbellarians. Nematodes numerically dominated all sampled stations, comprising more than $45 \%$ of the total meiofauna density. Meiofauna was mainly concentrated at the sand surface with about $70 \%$ present in the uppermost $5 \mathrm{~cm}$. Meiofauna occurred across the entire intertidal zone. A clear zonation pattern in the distribution of meiofauna taxa across the beaches was observed. The present work suggests that designation of exposed sandy beaches as physically controlled (McLachlan 1988) does not explain their biological variability.
\end{abstract}

Keywords Sandy beach - Meiofauna - Vertical and horizontal distribution $\cdot$ North Sea

Communicated by H.-D. Franke

L. Kotwicki $(\square) \cdot$ B. Urban-Malinga · J. M. Weslawski Institute of Oceanology Polish Academy of Sciences, Powstancow Warszawy 55, 81-712, Sopot, Poland

M. D. Troch · T. Gheskiere

Biology Department, Marine Biology Section, Ghent University, Krijgslaan 281 / S8, 9000, Gent, Belgium

\section{Introduction}

The European coast consists for more than $30 \%$ of soft sediments. Sandy shorelines are one of the most extensive intertidal systems worldwide (Short 1999), dominating most of the temperate coastlines, where they represent both excellent recreational assets and buffer zones against the sea (Davies 1972). As an example, the coastline of France $(3,830 \mathrm{~km})$ consists for about $40 \%$ of sandy sediments (Richard and Dauvin 1997) while Belgium and the Netherlands are characterised by exclusively sandy coastlines. Despite their initial barren and sterile appearance, many sandy beaches support a diverse flora and fauna, and a number of sandy littoral localities might even be considered as highly productive (McLachlan 1983).

Most of the faunal research on sandy beaches has been concentrated on macrofauna $(>1 \mathrm{~mm}$ ) (McLachlan and Jaramillo 1995, and references therein) and more recently also birds (e.g. Cornelius et al. 2001). In contrast, sandy shoreline meiofauna (all metazoans between $1 \mathrm{~mm}$ and $38 \mu \mathrm{m})$ have received considerably less attention notwithstanding their high diversity (even on taxon level) and density (up to one million individuals per $\mathrm{m}^{2}$ (McIntyre 1969).

With the recent increasing interest in faunal zonation patterns of meiobenthos on sandy shorelines, several quantitative studies have been made of European intertidal sandy beaches (Renaud-Debyser 1963; Renaud-Debyser and Salvat 1963; Fenchel et al. 1967; Jansson 1968; Schmidt 1968; Gray and Rieger 1971; Harris 1972; Schmidt 1972; Arlt 1977; Jonczyk and Radziejewska 1984; Armonies and Hellwig-Amonies 1987; Reise 1988; Ólafsson 1991; Armonies and Reise 2000; Gheskiere et al. 2004a, b). Much of the previous meiofauna research on sandy beaches is in essence restricted to general surveys using bulk samples or to the complex of factors influencing the interstitial habitats (Blome et al. 1999) while vertical and horizontal zonation surveys are scarce. 
Meiofauna inhabiting Belgian sandy beaches has been poorly documented. Horizontal distribution of the Plathelminthes and Nematoda (Mariakerke and De Panne region) were described by Martens (1984), Jouk et al. (1988) and Gheskiere et al. (2002, 2004). Meiofauna (on the Nematoda species level) of the Westerschelde was investigated along a salinity transect by Soetaert et al. (1994), however this study excluded the sandy beaches of this estuary.

Given the importance of sandy beaches for the marine ecosystem, baseline data describing the benthic life and ecosystem processes are needed in order to propose sustainable management policies for these sandy areas. Furthermore, sandy beaches have a high socio-economical value, as it is reflected in their importance for coastal fisheries and tourism. Each year high numbers of tourists are visiting the European coastlines. Although beaches are impacted by numerous stress factors, man has always used sandy beaches and will continue to do so, partly through ignorance and inability to learn from experience but also in the belief that it must be possible to shape nature to his own needs and desires (Brown and McLachlan 1990).

In the present study, 'beach' is defined as 'the zone between lowest and highest water mark, the swept prism, undergoing periodical inundation by marine water' (Short 1999). In this study, we focus on dissipative, medium-grained sandy beaches with a macrotidal regime sensu Short.

Since the work of McLachlan (1988), exposed sandy beaches have been considered as physically stressful environments. Thus, one expects that the interstitially living meiofaunal communities are regulated by physical rather than by biological factors. As there is a full array of organisms from bacteria (decomposers), microphytobenthos (producers) and meio- and macrofauna (consumers) to fish and birds (top trophic levels), we consider sandy beaches as open, functional entity-ecosystems. Hence, we aimed to get a two-dimensional view of meiofauna distribution on sandy beaches, that is, both horizontal and vertical distribution patterns.

\section{Methods}

Six sandy beaches along the North Sea were surveyed in 2000 (Fig. 1). In the Netherlands two intertidal sites (indicated as Westerschelde 1 and Westerschelde 2) were investigated. Three major European rivers (the Rhine, Meuse and Schelde) enter the North Sea in the so-called Dutch Delta in the south-western part of the Netherlands. Most of the former estuaries in this area have been altered by man. The lower part of the river Schelde is generally known as the Westerschelde estuary. It is the last true estuary of the Delta area in the southwest of the Netherlands with a marked salinity gradient (Soetaert et al. 1994). The input of organic and inorganic pollutants is very high (Hummel et al.

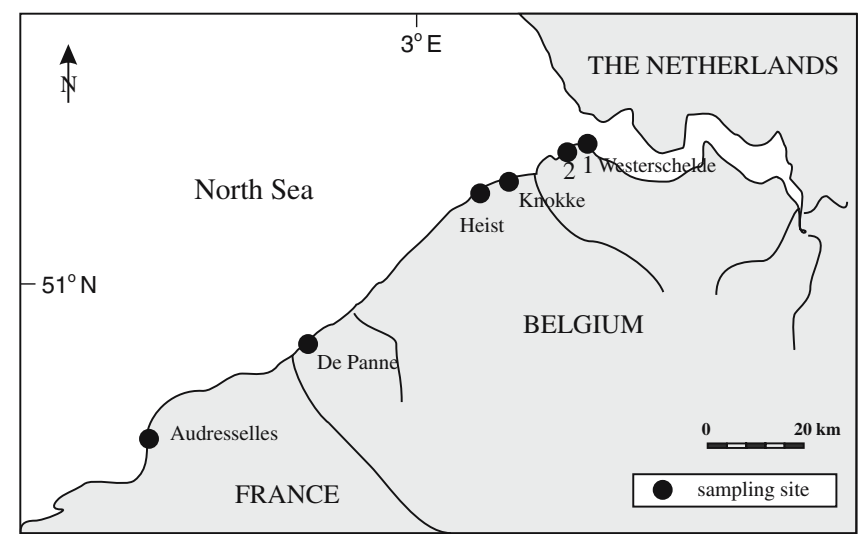

Fig. 1 Location of the investigated sandy beaches

1988). The study sites were in the brackish intertidal zone of the Westerschelde estuary, a turbid, nutrientrich, heterotrophic system. Most of the tidal flat where samples have been taken is located between $-1 \mathrm{~m}$ and $+1 \mathrm{~m}$ relative to mean tidal level and is subjected to tidal amplitudes of about $5 \mathrm{~m}$. The sampling stations (Westerschelde 1 and Westerschelde 2) have a silt percentage of up to $3 \%$ (fraction $<63 \mu \mathrm{m}$ ) and a median grain size of 168 and $230 \mu \mathrm{m}$, respectively (Hummel et al. 1988; Soetaert et al. 1994).

In Belgium three sandy beaches were studied (Heist, Knokke-Heist and De Panne). The beaches sampled in Heist and De Panne are dissipative beaches, characterised by a low beach gradient, a surf zone with the presence of numerous spilling lines of breakers and by fine to medium sandy sediments. The beach in KnokkeHeist can be classified as a 'low tide bar/rip' beach [beach morphodynamical classification after (Masselink and Short 1993), and Short (1999)]. The width of the intertidal zone is up to $450 \mathrm{~m}$ with a Relative Tidal Range (RTR) of 8.5-10 m (Degraer et al. 2003). The beaches have several shallow depressions parallel to the waterline, in which water is retained when the tide recedes.

In France (North Brittany), a beach with medium sandy sediments in the Audresselles region was investigated. This beach is characterized by an intertidal zone of about $200 \mathrm{~m}$ with a RTR up to $8 \mathrm{~m}$.

At each of the sampling stations triplicate meiofauna samples $(0-10 \mathrm{~cm})$ were taken using a $30 \mathrm{~cm}$ long perspex meiocore with an inner diameter of $3.6 \mathrm{~cm}$ (sampling surface $10 \mathrm{~cm}^{2}$ ) and immediately fixed with heated $\left(70^{\circ} \mathrm{C}\right) 4 \%$ buffered formaldehyde water solution (Vincx 1996).

In order to analyse the vertical distribution of the meiofauna, mid-tidal level samples from four sandy beaches (Westerschelde 1 and 2, Knokke-Heist, Audresselles) were subdivided into nine depth horizons ( 0 $0.5,0.5-1,1-1.5,1.5-2,2-2.5,2.5-3,3-4,4-5,5-10 \mathrm{~cm}$; Fig. 2a).

In order to analyse the horizontal distribution, two transects across the continuum from the mean high water spring level to the Mean Low Water Spring level 
Fig. 2 Sampling stations and sampling strategy applied for a Westerschelde, Knokke-Heist, Audresselles sandy beaches and b Heist, De Panne sandy beaches; $M H W S$ Mean High Water Springs, $M H W N$ Mean High Water Neaps, $M T$ Middle Tide, $M L W N$ Mean Low Water Neaps, $M L W S$ Mean Low Water Springs

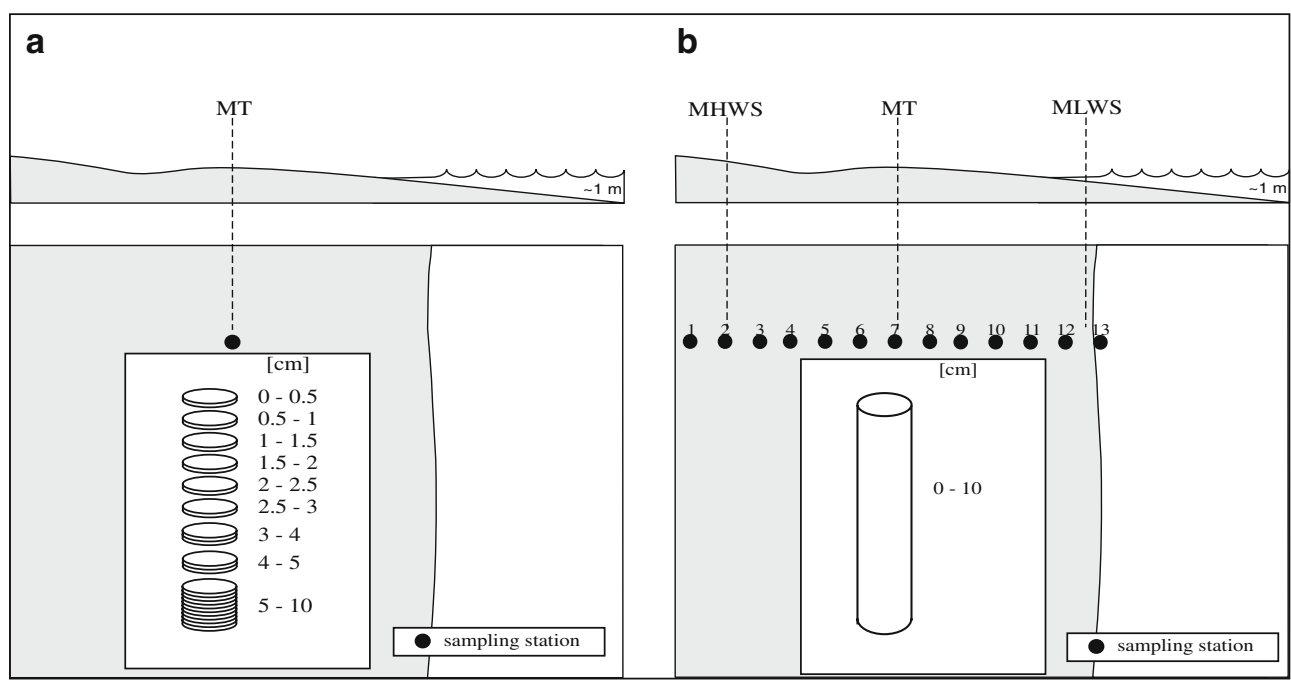

(MLWS) and perpendicular to the waterline were sampled (Fig. 2b), on the beaches of Heist and De Panne. The distance from the dyke to the shore was divided into 14 (De Panne) and 13 (Heist) separate stations according to the removing water line. Sampling began at high tide, and followed the receding water down to the beach. The highest station (station 1) was immediately in front of the storm-water dyke on the dry beach while the lowest (station 13 or 14) was about $1 \mathrm{~m}$ below the MLWS level.

In the laboratory meiofauna samples were processed using standard procedures as described by Vincx (1996).

To clarify meiofaunal zonation patterns across the studied beaches, polynomial functions were fit to the data according to the distance-weighted least squares smoothing procedure, using the STATISTICA 5.1 software (StatSoft 1996).

\section{Results}

Meiofauna taxa composition and their frequency of occurrence

Eleven higher taxa of meiofauna (one represented by larval stage - Copepoda nauplii) were recorded in the sandy beach zones (Table 1). The most common taxa were Nematoda, Harpacticoida, Turbellaria and Oligochaeta which were present at all stations, while Ostracoda, Tardigrada, Gastrotricha and Copepoda nauplii were less frequent (present in five out of six stations). Polychaeta, Bivalvia and Halacaroidea were found on 4, 3 and 3 beaches, respectively. The number of taxa on each beach ranged from 7 to 11 . The most diverse fauna, that is, 10 and 11 taxa, was observed in the samples of Westerschelde 1 and the beach of Heist, respectively.

\section{Density of the main taxa of meiofauna}

The highest meiofauna densities were observed on the Dutch beaches, that is, $4,295 \pm 911$ ind. $10 \mathrm{~cm}^{-2}$ at Westerschelde 1 , and 2,342 $\pm 1,101$ ind. $10 \mathrm{~cm}^{-2}$ at Westerschelde 2 (Table 2). In Belgium, at KnokkeHeist, Heist and De Panne the total meiofauna abundance was much lower, that is, 1,267 \pm 382 ind. $\quad 10 \mathrm{~cm}^{-2}, \quad 868 \pm 420$ ind. $\quad 10 \mathrm{~cm}^{-2}$ and $1,012 \pm 311$ ind. $10 \mathrm{~cm}^{-2}$, respectively. The lowest values $\left(361 \pm 128\right.$ ind $\left.10 \mathrm{~cm}^{-2}\right)$ were noted in France at the Audresselles beach. Nematodes were numerically dominant at all beaches, ranging from $235 \pm 116$ ind. $10 \mathrm{~cm}^{-2}$
Table 1 Distribution of the meiofauna taxa in the different study sites

\begin{tabular}{|c|c|c|c|c|c|c|}
\hline \multirow[t]{2}{*}{ Taxon } & \multicolumn{6}{|l|}{ Study sites } \\
\hline & Westerschelde 1 & Westerschelde 2 & Knokke-Heist & Heist & De Panne & Audresselles \\
\hline Nematoda & + & + & + & + & + & + \\
\hline Harpacticoida & + & + & + & + & + & + \\
\hline Turbellaria & + & + & + & + & + & + \\
\hline Ostracoda & + & + & + & + & + & - \\
\hline Tardigrada & + & - & + & + & + & + \\
\hline Gastrotricha & + & + & + & + & + & - \\
\hline Copepoda nauplii & + & - & + & + & + & + \\
\hline Oligochaeta & + & + & + & + & + & + \\
\hline Bivalvia & + & + & - & + & - & - \\
\hline Polychaeta & + & - & - & + & + & + \\
\hline Halacaroidea & - & - & + & + & + & - \\
\hline Number of taxa & 10 & 7 & 9 & 11 & 10 & 7 \\
\hline
\end{tabular}


in the Audresselles region up to $4,116 \pm 805$ ind. $10 \mathrm{~cm}^{-2}$ on the Westerschelde 2 beach. Turbellaria were subdominant in terms of average density at all beaches except for the Knokke-Heist region, with mean abundances from $16 \pm 11$ (Westerschelde 2) up to $215 \pm 11$ ind. $10 \mathrm{~cm}^{-2}$ (Heist). On the Knokke-Heist beach harpacticoids were of secondary importance, reaching a mean density of $384 \pm 226$ ind. $10 \mathrm{~cm}^{-2}$. The lowest density of this taxon was observed in the Westerschelde region with only $3.7 \pm 2$ ind. $10 \mathrm{~cm}^{-2}$. The taxon Ostracoda was important in meiofauna composition in the Westerschelde 1 region, attaining $130 \pm 61$ ind. $10 \mathrm{~cm}^{-2}$. Polychaeta and Halacaroidea were important groups in terms of meiofaunal densities, with $63 \pm 36$ and $59 \pm 100$ ind. $10 \mathrm{~cm}^{-2}$, respectively, on the beach of Heist.

\section{Relative meiofauna composition}

At all stations, Nematoda comprised more than $45 \%$ of the total meiofaunal density (Fig. 3). They were particularly dominant (96 and 93\%) in the Westerschelde region. The lowest percentage of this taxon $(46 \%)$ was noted on the Heist beach. Harpacticoida were the second important group in the Knokke-Heist region, comprising $30 \%$ of the meiofauna density. On other beaches the percentage of Harpacticoida varied from less than $1 \%$ (Westerschelde 1) up to $11 \%$ (Heist). The percentage of Turbellaria, as second important taxon in Audresselles and the Heist region, reached 19 and 25\% of the total meiofaunal density, respectively. Other meiofaunal taxa occurring in smaller numbers were grouped as 'Others'.

Vertical distribution of meiofauna taxa in a sandy beach zone

Depth distribution patterns of Nematoda, Harpacticoida and Turbellaria were analysed at four midtidal

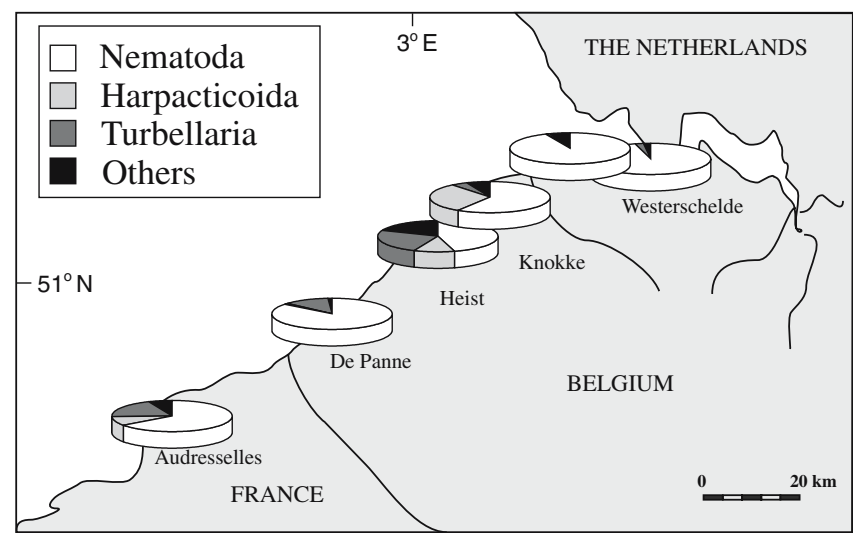

Fig. 3 Relative abundance of major meiofauna taxa at different sampling sites

sampling stations (Fig. 4). The meiofauna was mainly concentrated at the sand surface, with about $70 \%$ present in the upper first $5 \mathrm{~cm}$. Nematoda were found at all depth intervals. The vertical distribution of the nematodes was rather uniform at three stations $(\mathrm{Au}-$ dresselles, Westerschelde 1 and 2), with about $90 \%$ present in the top $5 \mathrm{~cm}$, and more than $56 \%$ in the first $2 \mathrm{~cm}$. A different situation was observed at the Knokke-Heist beach where nematodes occurred deeper within the sediments, although they were still most abundant in the top layers. Harpacticoida were largely confined to the surface layer, above $80 \%$ within the first $2 \mathrm{~cm}$ at all stations. Harpacticoida were found in high numbers only at the station in Knokke-Heist, where they showed the general vertical distribution pattern. Turbellaria were found at all depth intervals examined, yet highest densities were found in the 1$2 \mathrm{~cm}$ layer of the sediment.

Nematodes were dominant in all layers from the Westerschelde samples, comprising more than $84 \%$ of the total meiofauna density (Fig. 5). Nematoda also dominated on the beach of Knokke-Heist in the deeper

Table 2 Density of the meiofauna taxa at the different sampling sites in the $1-10 \mathrm{~cm}$ layers of sediment mean abundance

\begin{tabular}{|c|c|c|c|c|c|c|c|c|c|c|c|c|}
\hline \multirow[t]{3}{*}{ Taxon } & \multicolumn{4}{|c|}{ Westerschelde } & \multicolumn{2}{|c|}{ Knokke-Heist } & \multicolumn{2}{|l|}{ Heist } & \multicolumn{2}{|c|}{ De Panne } & \multicolumn{2}{|c|}{ Audresselles } \\
\hline & \multicolumn{2}{|l|}{ W 1} & \multicolumn{2}{|l|}{ W 2} & \multirow[t]{2}{*}{ M } & \multirow[t]{2}{*}{ SD } & \multirow[t]{2}{*}{ M } & \multirow[t]{2}{*}{ SD } & \multirow[t]{2}{*}{ M } & \multirow[t]{2}{*}{ SD } & \multirow[t]{2}{*}{ M } & \multirow[t]{2}{*}{ SD } \\
\hline & M & SD & M & SD & & & & & & & & \\
\hline Nematoda & 4116.3 & 805 & 2187.0 & 1,050 & 747.7 & 133 & 395.8 & 314 & 866.3 & 285 & 235.0 & 116 \\
\hline Harpacticoida & 3.7 & 2 & 6.7 & 2 & 384.0 & 226 & 92.8 & 19 & 9.7 & 5 & 33.7 & 18 \\
\hline Turbellaria & 94.0 & 50 & 15.7 & 11 & 55.7 & 28 & 214.7 & 11 & 125.7 & 47 & 69.0 & 41 \\
\hline Ostracoda & 61.3 & 40 & 129.7 & 61 & 0.3 & 1 & 28.3 & 42 & - & - & - & - \\
\hline Tardigrada & 0.3 & 1 & - & - & 39.0 & 21 & 0.2 & 0 & 2.7 & 3 & 4.3 & 8 \\
\hline Gastrotricha & 12.7 & 9 & 1.3 & 2 & 9.0 & 3 & 1.8 & 1 & 2.7 & 1 & - & - \\
\hline Copepoda nauplii & 1.0 & 1 & - & - & 23.3 & 5 & 11.8 & 10 & 0.7 & 1 & 1.0 & 2 \\
\hline Oligochaeta & 5.0 & 3 & 2.0 & 2 & 8.3 & 5 & 0.7 & 0 & 4.3 & 3 & 2.0 & 3 \\
\hline Bivalvia & 0.3 & 1 & 0.3 & 1 & - & - & - & - & - & - & - & - \\
\hline Polychaeta & 0.7 & 1 & - & - & - & - & 63.0 & 36 & - & - & 16.0 & 16 \\
\hline Halacaroidea & - & - & - & - & 0.3 & 1 & 59.2 & 100 & - & - & - & - \\
\hline Total & 4295.3 & & 2342.7 & & 1267.7 & & 868.3 & & 1012.0 & & 361.0 & \\
\hline
\end{tabular}

$M$ Individuals per $10 \mathrm{~cm}^{2} \pm$ standard deviation (SD) 
Fig. 4 Vertical distribution of Nematoda, Harpacticoida and Turbellaria at the sampling stations Westerschelde 1 and 2, Knokke-Heist and Audresselles
Fig. 5 Vertical distribution of meiofauna: relative abundance of major meiofauna taxa in different depth layers
Westerschelde 1
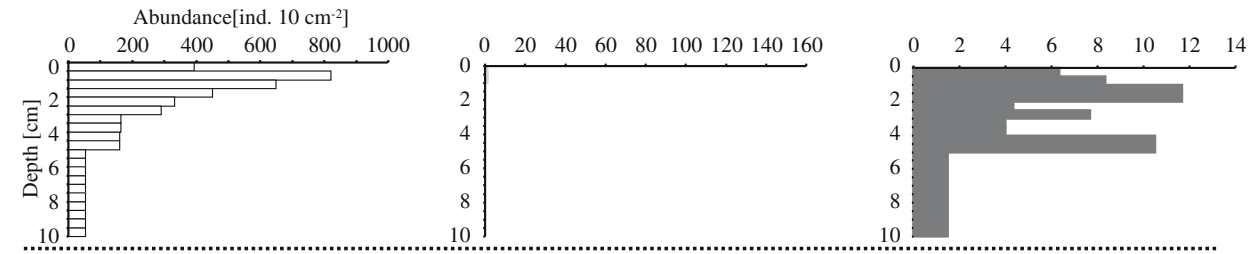

Westerschelde 2
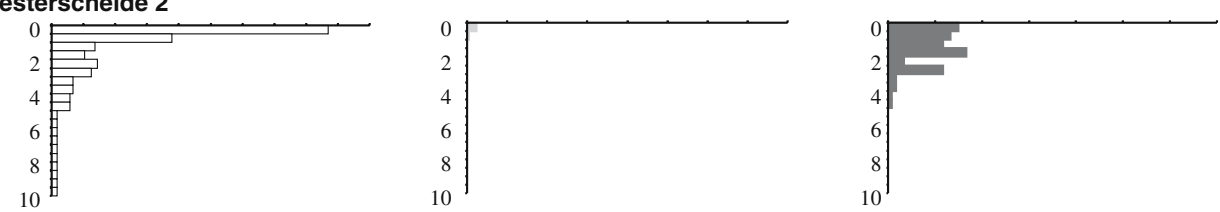

Knokke-Heist
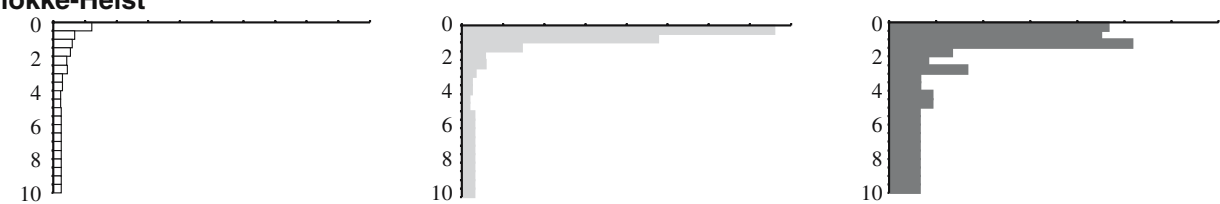

\section{Audresselles}
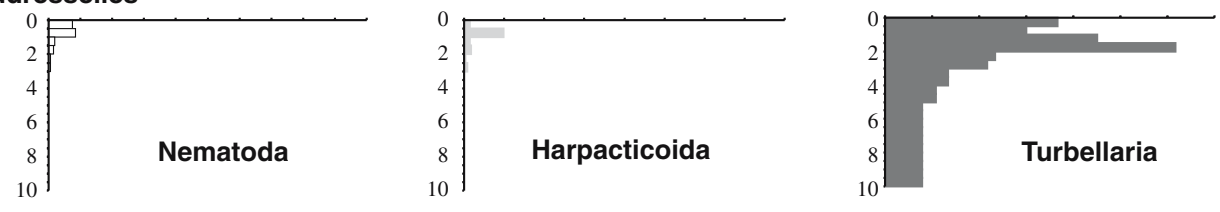

Westerschelde 1 Westerschelde 2 Knokke-Heist

Audresselles
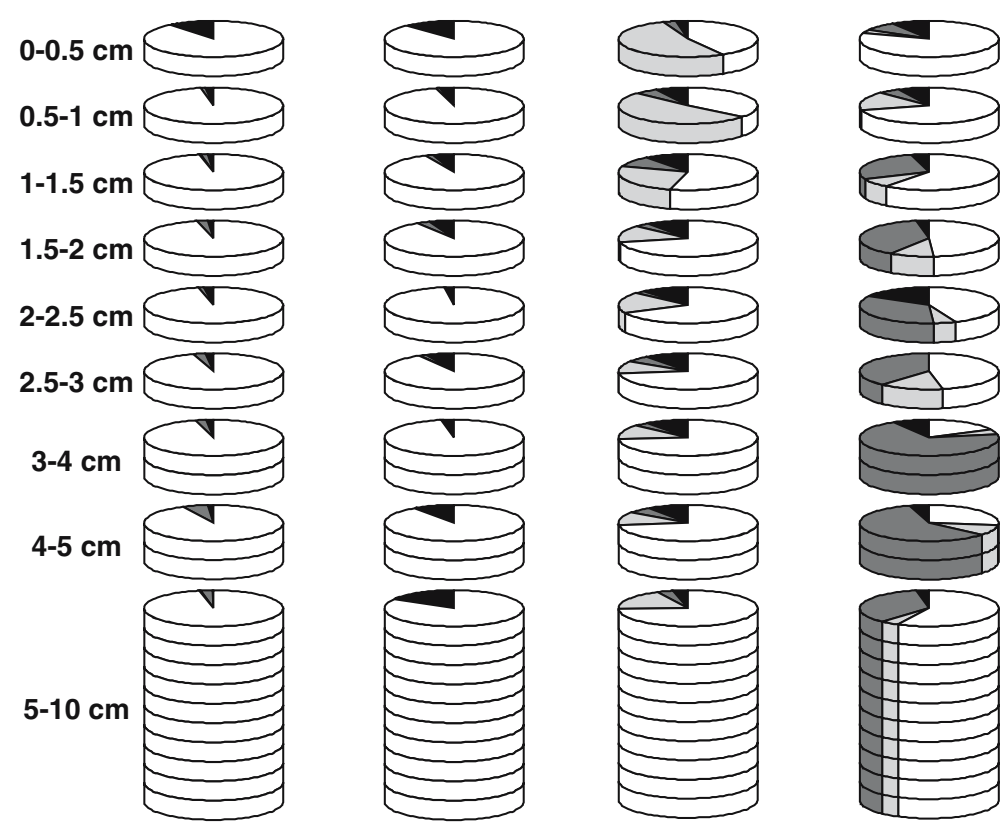

Harpacticoida

Others layers from $54 \%(1-1.5 \mathrm{~cm})$ to $75 \%(5-10 \mathrm{~cm})$. In the top layers $(0-0.5 \mathrm{~cm}$ and $0.5-1 \mathrm{~cm})$, however, harpacticoids were dominant with 52 and $51 \%$ of the total meiofauna abundance, respectively. The percentage of Harpacticoida decreased towards deeper layers and the percentage of Nematoda increased with depth. In the Audresselles samples Nematoda and Turbellaria were dominant in total meiofaunal abundance. The percentage of nematodes decreased towards deeper layers from about $75 \%$ on the surface to $15 \%$ in the $4-5 \mathrm{~cm}$ layer. In 
the deepest $5-10 \mathrm{~cm}$ layer of the sediment nematodes were dominant comprising about $60 \%$ of the meiofauna abundance.

The maximum percentage of turbellarians in meiofauna abundance was found in the 3-4 and $4-5 \mathrm{~cm}$ layers, with 70 and $59 \%$, respectively. Their percentage decreased towards the sediment surface and was lower in the deepest layer $(5-10 \mathrm{~cm})$.

Horizontal distribution of the meiofauna at the sandy beaches of Heist and De Panne

Polynomial functions, showing the general intertidal zonation trends of the meiofauna abundance on two sandy beaches (Heist and De Panne), were developed using a distance-weighted, least squares smoothing procedure in the Statistica v 6.1 software package (Fig. 6). The trend lines do not show min and max values in Fig. 6, the data of meiofauna abundance are presented in Table 3. Different zonation patterns of the meiofauna were observed for the two investigated beaches. Meiofauna was generally recorded through the whole intertidal zone.

At Heist beach, average density of meiofauna per station ranged from 52 (station 1) to 1,169 ind. $10 \mathrm{~cm}^{-2}$ (station 8). From the mid-tidal zone towards the MLWS a general decrease in meiofauna density was observed.

At De Panne beach, average meiofaunal density per station varied from 83 ind. $10 \mathrm{~cm}^{-2}$ (station 1) to almost

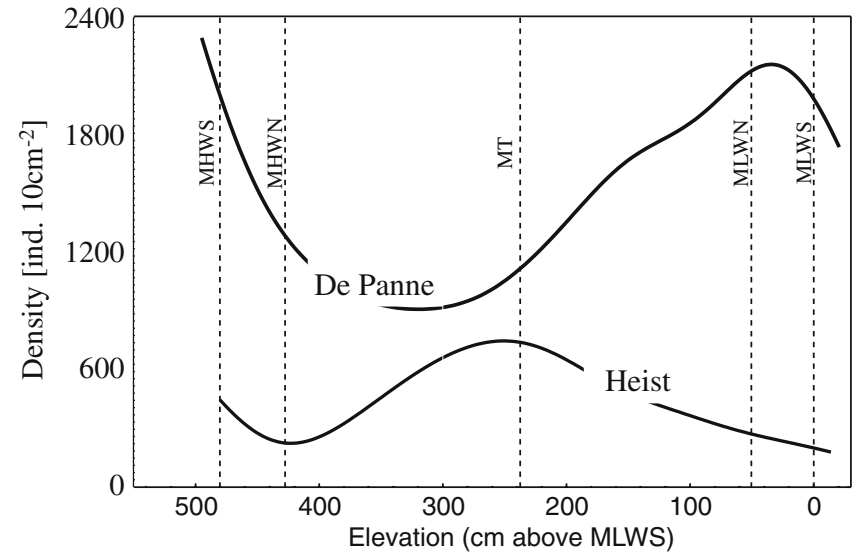

Fig. 6 The general intertidal zonation trends (polynomial function) of distribution of meiofauna at the beaches of Heist and De Panne

3,400 ind. $10 \mathrm{~cm}^{-2}$ (station 12). In contrast to Heist, abundance of meiofauna decreased from station 2 (MHWS) towards the mid-intertidal zone (min. values-780 ind. $10 \mathrm{~cm}^{-2}$ at station 7) and then increased generally to the Mean Low Water Neap level (MLWN), reaching highest values $\left(3,385\right.$ ind $\left.10 \mathrm{~cm}^{-2}\right)$ at station 12.

The general intertidal zonation trends of major meiofauna taxa showed also a different pattern on the beaches of Heist and De Panne (Fig. 7). A similar, although different in numbers, density peak of nematodes was found at the MHWS at both beaches. A second

Table 3 Average abundance of meiofauna (individuals per $10 \mathrm{~cm}^{2}$ ) across the beaches of Heist (a) and De Panne (b)

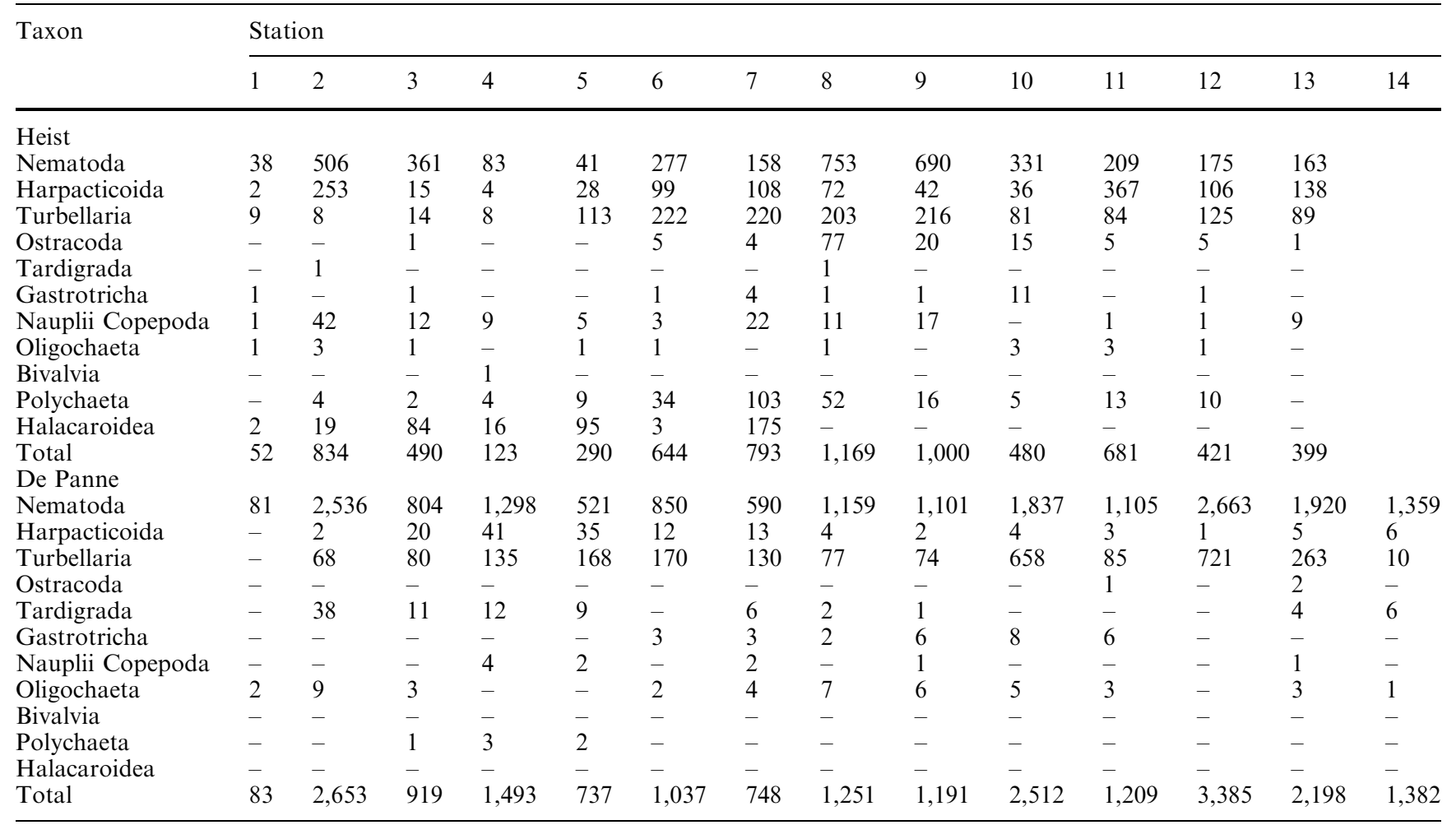



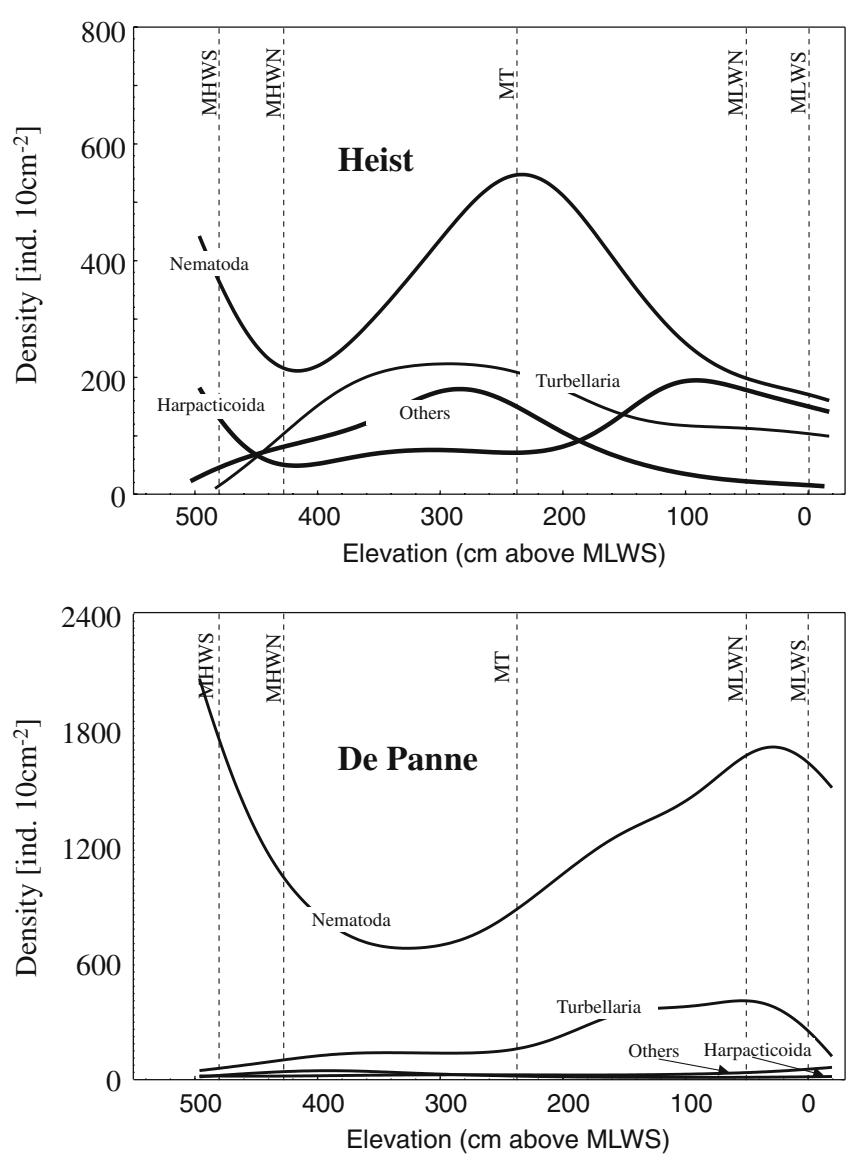

Fig. 7 The general intertidal zonation trends (polynomial function) of distribution of major meiofauna taxa at the beaches of Heist and De Panne

density peak of nematodes was observed in the Middle Tide (MT) at Heist beach, while at De Panne it was observed just below the MLWN. Also the distribution of Turbellaria showed different patterns on the two beaches. In the Heist region an increase towards the MT and a slight decrease towards the subtidal was observed. At De Panne beach, a smooth increase of turbellarian density from MHWS towards MLWN followed by a decrease to the subtidal was recorded. Only the distribution of Harpacticoida showed similar patterns at both beaches, that is, increasing density from MHWS towards MLWS.

\section{Statistical analyses}

Based on the results of cluster analysis using Bray-Curtis similarity index comparing the physical parameters of the studied beaches, two groups of beaches were distinguished: De Panne, Heist and Knokke-Heist on the one hand, and Westerschelde 1, 2 with Audresselles on the other (Fig. 8a). A different pattern of grouping was discerned when using meiofauna assemblage data (Fig. 8b).
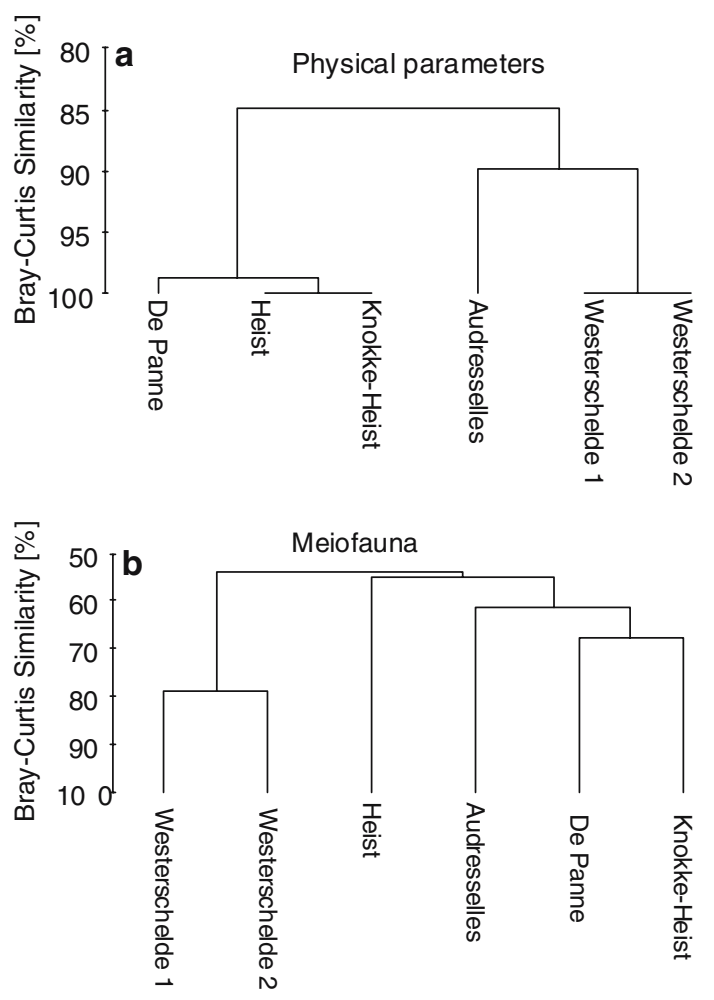

Fig. 8 Similarity of the investigated beaches based on a physical parameters, b meiofaunal assemblages

\section{Discussion}

Although this study is limited to six sites along the North Sea coast, several trends were observed. The average meiofauna densities recorded in the present study $\left(0.23-4.29 \times 10^{4}\right.$ ind. $\left.10 \mathrm{~cm}^{2}\right)$ are in general of the same order of magnitude as the meiofauna densities in sandy beaches reported in the literature (for overview, see Table 4). The highest abundance of meiofauna was observed in the Schelde estuary. In general, higher meiofauna densities can be found in intertidal estuarine habitats (Coull 1988). In sediments such as organic rich sand, meiofauna densities of $10^{4}$ ind $10 \mathrm{~cm}^{-2}$ and more are common (Ellison 1984). The highest values are known from intermediate beaches, where an optimal balance exists between organic input and oxygenation. These abundances, of course, vary according to temperature, tidal exposure, wave action, grain size, oxygen availability, substratum porosity, water percolation, organic input etc. (Gheskiere et al. 2005a). In addition, sediment grain size is a cardinal factor for the abundance and composition of meiofaunal organisms (Wieser 1959; Boaden 1962; Jansson 1967; Gray 1981; Coull 1988). In general, nematodes dominate benthic meiofauna communities comprising more than half of the total meiofauna abundance (Harris 1972; Dye 1983; McLachlan 1983). This was indeed the case for all sites sampled during this study. Harpacticoids are usually sub- 
Table 4 Overview of meiofauna densities (individuals per $10 \mathrm{~cm}^{2}$ ) reported from different sandy littoral sites

\begin{tabular}{|c|c|c|c|c|}
\hline Location & Nematoda & Copepoda & Meiofauna & Author \\
\hline Asko, Baltic Sea & $38-169$ & $29-830$ & $391-152$ & Jansson (1968) \\
\hline Tafta, Baltic Sea & $8-14$ & 0 & $225-104$ & Jansson (1968) \\
\hline Tylosand, Baltic Sea & $6-106$ & $1-52$ & $11-845$ & Jansson (1968) \\
\hline Oresund, North Sea & $115-497$ & $1-10$ & $249-764$ & Fenchel et al. (1967) \\
\hline Wadden Sea, Denmark & $10-1,050$ & $1-840$ & 13-191 & Smidt (1951) \\
\hline Blyth estuary, UK & $330-1,320$ & - & - & Capstick (1959) \\
\hline France, Big Channel & $2-268$ & $2-192$ & 19-389 & Renaud-Debyser and Salvat (1963) \\
\hline France, Atlantic & $61-204$ & $5-331$ & $83-591$ & Renaud-Debyser and Salvat (1963) \\
\hline White Sea, Russia & $7-239$ & $20-261$ & $319-427$ & Galtsova (1971) \\
\hline Germany & $322-1,559$ & $34-93$ & $636-1,837$ & Arlt (1977) \\
\hline Delaware, USA & $57-538$ & $2-8$ & $125-896$ & Hummon et al. (1976) \\
\hline New York, USA & $1-2,262$ & $0-34$ & $4-2,293$ & Martinez (1975) \\
\hline Alaska, USA & $300-2,900$ & $86-1,249$ & $420-4,790$ & Feder and Paul (1980) \\
\hline India & $584-4,597$ & $102-888$ & $2,270-6,116$ & Ansari and Ingole (1983) \\
\hline Baltic beach, Poland & - & - & $325-2,250$ & Jonczyk and Radziejewska (1984) \\
\hline Kali estuary, India & - & - & $129-4,731$ & Bhat and Neelakantan (1991) \\
\hline Sylt island, Niemcy & - & - & $4,812-6,960$ & Armonies and Hellwig-Armonies (1987) \\
\hline York, Australia & - & - & $66-302$ (winter) & Alongi (1987) \\
\hline York, Australia & - & - & 217-1,672 (summer) & Alongi (1987) \\
\hline Gopalpur, India & - & - & $52-5,249$ & Pattnaik and Lakshmana Rao (1990) \\
\hline
\end{tabular}

dominant in terms of density (McIntyre 1969). A different situation was observed in the Westerschelde region where Harpacticoida were found in very low densities. Apart from a few exceptions (Vopel et al. 1996), copepods are generally more sensitive to oxygen depletion or anoxia than nematodes (Elmgren 1975; Murrell and Fleeger 1989; Moodley et al. 2000; Modig and Ólafsson 1998) which may possibly explain this pattern. The input of organic and inorganic pollutants is very high in the Schelde estuary (Hummel et al. 1988). It is also interesting to note the remarkably low percentage $(1 \%$ of total meiofauna density) of copepods in De Panne beach. Other taxa (Turbellaria, Ostracoda, Oligochaeta, Gastrotricha) were found on most beaches but the numerical relationship between them varies. A similar pattern was observed on other European sandy beaches (Jansson 1968; Feder and Paul 1980; Jończyk and Radziejewska 1984).

Vertical zonation is generally controlled by the position of the Redox Potential Discontinuity (RPD) layer (Coull 1988; Steyaert and Vincx 1996). The meiofauna was mainly concentrated on the sand surface, with about $70 \%$ present in the top $5 \mathrm{~cm}$. Nematodes were found at all depth intervals. Harpacticoid copepods are the most sensitive taxon to decreased oxygen (Moodley et al. 2000). This taxon was almost confined to the surface layer, above $80 \%$ in the first $2 \mathrm{~cm}$ at all stations. Turbellaria were found at every depth interval examined but they were generally more abundant in the $1-2 \mathrm{~cm}$ layer of the sediment. This pattern, that is, meiofauna abun- dance maxima in the upper $2 \mathrm{~cm}$ of sediment, was recorded by almost all meiobenthic studies. Occasionally, sandy beach meiofauna can be distributed to the depth of $50 \mathrm{~cm}$ or deeper on well-oxygenated beaches (Brown and McLachlan 1990). Munro et al. (1978) recorded nematodes down to $105 \mathrm{~cm}$ at such beaches. McLachlan (1977) suggested that meiofauna remains mainly in conditions where oxygen is plentiful, but also escape from desiccation and feeding activity may affect vertical distribution. The latter was confirmed by studying finescaled vertical distribution patterns of marine nematodes (Steyaert et al. 2001, 2003). Moodley et al. (2000) and Widbom and Elmgren (1988) turned attention onto microfaunal (ciliate and protozoan) activity in the sandy beach sediments as an important factor governing the subsurface activity of meiofauna. In addition, anthropogenic factors (e.g. pollution, physical disturbance) may influence distribution of meiofauna in the sediment as well (Schratzberger and Warwick 1998; Gheskiere et al. 2005b).

Community patterns and abundance in exposed sandy beaches have been assumed to be primarily controlled by specific responses to water percolation processes and sediment characteristics (McLachlan 1977; McLachlan et al. 1993). Exposed sandy beaches have been considered physically stressful environments, their faunal assemblages being best understood by observing responses to abiotic factors (Jaramillo and McLachlan 1993). The 'biotic factors in stable environment' theory of Hulings and Gray (1976) stated that biological 
Table 5 Sedimentological and morphodynamic characteristic of the Heist and De Panne beaches (after Degraer et al. 2003)

\begin{tabular}{llllllll}
\hline & Slope $\left(^{\circ}\right)$ & \multicolumn{2}{l}{ Grain size $(\mu \mathrm{m})$} & & \multirow{2}{l}{ RTR } & BSI \\
\cline { 3 - 5 } & & Min-max & Mean & & & \\
\hline Heist & 0.7 & $227-275$ & 255 & 6.8 & 10.0 & 4.2 \\
De Panne & 0.7 & $177-235$ & 199 & 6.2 & 8.7 & 3.4 \\
\hline
\end{tabular}

$\Omega$ (dimensionless) Dean's parameter of dimensionless fall velocity, $R T R$ (dimensionless) Relative Tidal Range, BSI (dimensionless) Beach State Index

interactions control meiofauna abundances on atidal beaches, while on tidal beaches sediment characteristics are the major controlling factors.

Biological factors are known to play a key role in the establishment and maintenance of macrofauna zonation on rocky shores, with recruitment, predation and competition all playing main roles (Menge and Sutherlands 1976; Underwood and Denley 1984). Thus, predation and competition for food might be important for the zonation of meiofauna on sandy beaches as well, although factors controlling these communities are not necessarily the same as on rocky shores. Zonation on sandy beaches is not nearly as visible as on rocky shores and is in fact three-dimensional. This is a consequence of the dynamic environment of the beach and the shifting of populations that occupy it (McLachlan and Jaramillo 1995). The present study aimed to incorporate at least two dimensions that is, vertical and horizontal distribution.

Although the present paper mainly relates physical factors to meiofauna distribution, some clear trends of niche segregation could be found. Even at the studied higher taxon level, meiofauna organisms showed preferences both in vertical and horizontal ranges. This suggests a taxon-specific distribution which is closely linked to a taxon-specific sensitivity to major abiotic factors. These abiotic factors seem to be very variable among the different beaches studied and this is reflected in different vertical distribution patterns of meiofauna at the sampling sites. In addition, the horizontal distribution of meiofauna along two nearby macro-tidal beaches (Table 5) showed strong differences suggesting that tidal range alone cannot explain most of the variation. In this way, meiofauna is a good predictor for the overall condition of a beach and might be very useful in further monitoring studies.

Acknowledgements The first author would like to thank his colleagues from Ghent University, Marine Biology Section, especially director Prof. Magda Vincx. Dr. Tom Moens is acknowledged for his assistance during the sampling campaigns.

\section{References}

Alongi DM (1987) Intertidal zonation and seasonality of meiobenthos in tropical mangrove estuaries. Mar Biol 95:447-458
Ansari ZA, Ingole BS (1983) Meiofauna on some sandy beaches of Andaman Islands. Indian J Mar Sci 12:245-246

Arlt G (1977) Verbreitlung und Artenspektrum der Meiofauna im Greifswalder Bodden Wissenschaftliche Zeitschrift der Universität Rostock. Mathematisch-Naturwissenschaftliche Reihe 26:217-222

Armonies W, Hellwig-Armonies M (1987) Synoptic patterns of meiofaunal and macrofaunal abundances and specific composition in littoral sediments. Helgoländer Meersunters 41:83-111

Armonies W, Reise K (2000) Faunal diversity across a sandy shore. Mar Ecol Prog Ser 196:49-57

Bhat UG, Neelakantan B (1991) Distribution of meiobenthos in relation to environmental parameters in the Kali estuary, Karwar. Comp Physiol Ecol 16:60-68

Blome D, Schleier U, von Bernem K-U (1999) Analysis of the small-scale spatial patterns of free-living marine nematodes from tidal flats in the East Frisian Wadden Sea. Mar Biol 133:717-726

Boaden PJS (1962) Colonization of graded sand by an interstitial fauna. Cah Biol Mar 8:245-248

Brown AC, McLachlan A (1990) Ecology of sandy shores. Elsevier, Amsterdam

Capstick CK (1959) The distribution of free-living nematodes in relation to salinity in the meddle and upper reaches of the River Blyth estuary. J Anim Ecol 28:189-210

Cornelius C, Navarrete SA, Marquet P (2001) Effects of human activity on the structure of coastal marine birds assemblages in Central Chile. Conserv Biol 15:1396-1404

Coull BC (1988) Ecology of the marine meiofauna. In: Higgins RP, Thiel $\mathrm{H}$ (eds) Introduction to the study of meiofauna. Smithsonian Institution Press, Washington DC, pp 18-38

Davies JL (1972) Geographical variation in coastal development. Longmans, London

Degraer S, Volckaert A, Vincx M (2003) Macrobenthic zonation patterns along a morphodynamical continuum of macrotidal, low tide bar/rip and ultra-dissipative sandy beach. Estuar Coast Shelf Sci 56:459-468

Dye AH (1983) Vertical and horizontal distribution of meiofauna in mangrove sediments in Transkei, Southern Africa. Estuar Coast Shelf Sci 16:591-598

Ellison RL (1984) Foraminifera and meiofauna on an intertidal mudflat, Cornwall, England: populations; respiration and secondary production; and energy budget. Hydrobiologia 109:131-148

Elmgren R (1975) Benthic meiofauna as indicator of oxygen condition in the Northern Baltic proper. Merentutkimuslait Julk 239:265-271

Feder HM, Paul AJ (1980) Seasonal trends in meiofauna abundance on two beaches in Port Valdez, Alaska. Syesis 13:27-36

Fenchel T, Jansson BO, von Thun W (1967) Vertical and horizontal distribution of the metazoan microfauna and of some physical factors in a sandy beach in the northern part of the Oresund. Ophelia 4:227-243

Galtsova VV (1971) A quantitative characteristic of meiobenthos in the Chupinsky inlet of the White Sea. Zoologischeskii Zhurnal 50:641-647

Gheskiere T, Hoste E, Kotwicki L, Degraer S, Vanaverbeke J, Vincx M (2002) The sandy beach meiofauna and free-living nematodes from De Panne (Belgium). Bull Inst Roy Sci Nat Belg 72(suppl):43-54

Gheskiere T, Hoste E, Vanaverbeke J, Degraer S, Vincx M (2004) Horizontal zonation patterns and feeding structure of marine nematode assemblages on a macrotidal, ultra-dissipative sandy beach (De Panne, Belgium). J Sea Res 52:211-226

Gheskiere T, Vincx M, Urban-Malinga B, Rossano C, Scapini F, Degraer S (2005a) Nematodes from wave-dominated sandy beaches: diversity, zonation patterns and testing of the isocommunities concept. Estuar Coast Shelf Sci 62:365-375

Gheskiere T, Vincx M, Weslawski JM, Scapini F, Degraer S (2005b) Meiofauna as descriptor of tourism-induced changes at sandy beaches. Mar Environ Res 60:245-265 
Gray JS (1981) The ecology of marine sediments. Cambridge University Press, New York

Gray JS, Rieger R (1971) A quantitative study of meiofauna of an exposed sandy beach, at Robin Hoods Bay, Yorkshire. J Mar Biol Ass UK 51:1-19

Harris RP (1972) The distribution and ecology of the interstitial meiofauna of a sandy beach at Whitsand Bay, East Cornwall. J Mar Biol Ass UK 52:1-18

Hulings NC, Gray JS (1976) Physical factors controlling abundance of meiofauna on tidal and atidal beaches. Mar Biol 34:77-83

Hummel H, Moerland G, Bakker C (1988) The concomitant existence of a typical coastal and a detritus food chain in the Westerschelde Estuary. Hydrobiol Bull 22:35-41

Hummon WD, Fleeger JW, Hummon, MR (1976) Meiofaunamacrofauna interactions: I Sand beach meiofauna affected by maturing Limulus eggs. Chesapeake Sci 17:297-299

Jansson BO (1967) The significance of grain size and pore water content for the interstitial fauna of sandy beaches. Oikos $18: 311-322$

Jansson BO (1968) Quantitative and experimental studies of the interstitial fauna in four Swedish sandy beaches. Ophelia 5:1-71

Jaramillo E, McLachlan A (1993) Community and population responses of the macroinfauna to physical factors over a range of exposed sandy beaches in south-central Chile. Estuar Coast Shelf Sci 37:615-624

Jonczyk E, Radziejewska T (1984) Temporal changes in sand meiofauna of a southern Baltic beach. Limnologica (Berlin) $15: 421-423$

Jouk PEH, Martens PM, Schockaert ER (1988) Horizontal distribution of the Plathelminthes in a sandy beach of the Belgian coast. In: Ax P, Ehlers U, Sopott-Ehlers B (eds) Free-living and symbiotic Plathelminthes (Progress in Zoology 36). Gustav Fischer Verlag, Stuttgart, pp 481-487

Martens PM (1984) Comparison of three different extraction methods for Turbellaria. Mar Ecol Prog Ser 4:229-234

Martinez EA (1975) Marine meiofauna of a New York City Beach, with particulate reference to the Tardigrada. Estuar Coast Shelf Sci 3:337-348

Masselink G, Short AD (1993) The effect of tide range of beach morphodynamics and morphology: a conceptual beach model. J Coast Res 9:785-800

McIntyre AD (1969) Ecology of the marine meiobenthos. Biol Rev 44:245-290

McLachlan A (1977) Composition, distribution, abundance and biomass of the macrofauna an meiofauna of four sandy beaches. Zool Afr 12:279-306

McLachlan A (1983) Sandy beach ecology - a review. In: McLachlan A, Erasmus T (eds) Sandy beaches as ecosystems. W. Junk, The Hague, pp 321-380

McLachlan A (1988) Behavioural adaptations of sandy beach organisms: an ecological perspective. In: Chelazzi G, Vannini M (eds) Behavioral adaptation to intertidal life. Plenum, New York, pp 449-475

McLachlan A, Jaramillo E (1995) Zonation on sandy beaches. Oceanogr Mar Biol 33:305-335

McLachlan A, Winter PED, Botha L (1977) Vertical and horicontal distribution of sublittoral meiofauna in Agoa Bay, South Africa. Mar Biol 40:355-364

McLachlan A, Jaramillo E, Donn T, Wessels F (1993) Sandy beach macrofauna communities and their control by the physical environment: a geographical comparison. J Coast Res 15:27-38

Menge BA, Sutherlands JP (1976) Species diversity gradients: synthesis of the roles of predation, competition and temporal heterogeneity. Am Nat 110:351-369

Modig H, Olafsson E (1998) Responses of Baltic benthic invertebrates to hypoxic events. J Exp Mar Biol Ecol 229:133-148

Moodley L, Chen G, Heip C, Vincx M (2000) Vertical distribution of meiofauna in sediments from contrasting sites in the Adriatic Sea: clues to the role of abiotic versus biotic control. Ophelia 53:203-212
Moore CG (1979) The distribution and ecology of psammolittoral meiofauna around the Isle of Man. Cah Biol Mar 20:383-415

Munro ALS, Wells JBJ, McIntyre AD (1978) Energy flow in the flora and meiofauna of sandy beaches. Proc R Soc Edinburgh 76B:297-315

Murrell MC, Fleeger JW (1989) Meiofauna abundance on the Gulf of Mexico continental shelf affected by hypoxia. Cont Shelf Res 9:1049-1062

Olafsson E (1991) Intertidal meiofauna of four sandy beches in Iceland. Ophelia 33:55-65

Pattnaik A, Lakshmana RMV (1990) Composition and distribution of interstitial meiofauna of the sandy beach at Gopalpur, south Orissa coast. Indian J Mar Sci 19:165-170

Reise K (1988) Plathelminth diversity in littoral sediments around the island of Sylt in the North Sea. Fortschr Zool 36:469-480

Renaud-Debyser J (1963) Recherches ecologiquessur la faune interstitielle des sables. Bassins d'Arcachon ile de Bimini. Vie Milieu 15:1-157

Renaud-Debyser J, Salvat B (1963) Elements de prosperite des biotopes des sediments meubles intertidaux et ecologie de leurs populations en microfaune et macrofauna. Vie Milieu 14:463550

Richard D, Dauvin JC (1997) Conservation strategies for French coastal areas. Aquat Conserv 7:205-214

Schmidt P (1968) Die quantitative Verteilung und Populationsdynamik des Mesopsammons am Gezeiten-Sandstrand der Norseeinsel Sylt. Int Rev ges Hydrobiol Hydrogr 53:723-799

Schmidt P (1972) Zonierung und jahreszeitliche Fluktuationen der interstitiellen Fauna in Sandstranden des Gebiets von Tromso (Norwegen). Mikrofauna des Meeresbodens 12:81-164

Schratzberger M, Warwick RM (1998) Effects of physical disturbance on nematode communities in sand and mud: a microcosm experiment. Mar Biol 130:643-650

Short AD (1999) Beach and shoreface morphodynamics. Wiley, Chichester

Smidt ELB (1951) Animal production in the Danish Waddensea. Meddr Danm Fisk -og Havunders 11:1-151

Soetaert K, Vincx M, Wittoeck J, Tulkens M, Van Gansbeke D (1994) Spatial patterns of Westerschelde meiobenthos. Estuar Coast Shelf Sci 39:367-388

Steyaert M, Herman PMJ, Moens T, Widdows J, Vincx M (2001) Tidal migration of nematodes on an estuarine tidal flat (the Molenplaat, Schelde Estuary, SW Netherlands). Mar Ecol Prog Ser 224:299-304

Steyaert M, Vanaverbeke J, Vanreusel A, Barranguet C, Lucas C, Vincx M (2003) The importance of fine-scale, vertical profiles in characterising nematode community structure. Estuar Coast Shelf Sci 58:353-366

Steyaert M. Vincx M (1996) The vertical distribution of meiobenthos in coastal sediments (Belgium). Bull Soc $r$ Sci Liège $65: 155-157$

Underwood AJ, Denley EJ (1984) Paradigms, explanations and generalizations in models for the structure of intertidal communities on rocky shores. In: Simberloff D (ed) Ecological communities: conceptual issues and evidence. Princeton, New Jersey, pp 151-180

Vincx M (1996) Meiofauna in marine and freshwater sediments. In: Hall GS (ed) Methods for the examination of organismal diversity in soil and sediments. Oxon, New York, pp 187-195

Vopel K, Dehmlow J, Arlt G (1996) Vertical distribution of Cletocamptus confluens (Copepoda, Harpacticoida) in relation to oxygen and sulphide microprofiles of a brackish water sulphuretum. Mar Ecol Prog Ser 141:129-137

Widbom B, Elmgren R (1988) Response of benthic meiofauna to nutrient enrichment of experimental marine ecosystems. Mar Ecol Prog Ser 42:257-268

Wieser W (1959) Free-living marine nematodes. II Chromadoria. Acta Univ Lund 59:1-148 